\title{
PROBLEMATIKA PROGRAM KREATIVITAS MAHASISWA (PKM) DAN PROGRAM MAHASISWA WIRAUSAHA (PMW) PADA FAKULTAS BAHASA DAN SENI UNDIKSHA
}

\author{
Sang Ayu Putu Sriasih ${ }^{1}$, Putu Kerti Nitiasih ${ }^{2}$ I Nyoman Adi Jayaputra ${ }^{3}$, \\ I Gede Budasi ${ }^{4}$, I Dewa Gede Budi Utama ${ }^{5}$ \\ Fakultas Bahasa dan Seni \\ Universitas Pendidikan Ganesha, Singaraja, Indonesia \\ e-mail: putu.sriasih@undiksha.ac.id ${ }^{1}$, titiek_jegeg@yahoo.com ${ }^{2}$, \\ ajp_undiksha@yahoo.com ${ }^{3}$, yaysurya8@yahoo.com ${ }^{4}$, budi.utama@undiksha.ac.id ${ }^{5}$
}

\begin{tabular}{|l|c|c|}
\hline (C) (P) & \multicolumn{2}{|c|}{$\begin{array}{l}\text { This is an open-access article under the CC BY-SA license. } \\
\text { Copyright } \odot 2020 \text { by Author. Published by Universitas Pendidikan Ganesha. }\end{array}$} \\
\hline Received : May, 2020 & Accepted : May, 2020 & Published : June, 2020 \\
\hline
\end{tabular}

\begin{abstract}
ABSTRAK
Program Kreativitas Mahasiswa (PKM) dan Program Mahasiswa Wirausaha (PMW) bertujuan untuk mengembangkan kemampuan soft skill dan aspek afektif, kognitif, maupun aspek psikomotor mahasiswa. Program ini memberikan manfaat bagi mahasiswa dan institusi. Banyak upaya telah dilakukan oleh sivitas Fakultas Bahasa dan Seni (FBS) Universitas Pendidikan Ganesha (Undiksha) dalam meningkatkan kuantitas dan kualitas PKM dan PMW. Namun dari data yang ada, kuantitas dan kualitasnya yang ada hingga saat ini masih sangat kurang. Dalam penelitian ini, penyebab kekurangan PKM dan PMW di FBS Undiksha diselidiki. Metode ADDIE (Analysis, Design, Development or Production, Implementation or Delivery, and Evaluations) diterapkan dalam penelitian ini. Data diperoleh melalui metode wawancara dari 91 mahasiswa FBS Undiksha. Hasil penelitian menunjukkan bahwa ada beberapa kendala yang dihadapi oleh mahasiswa ketika bergabung dengan PKM dan PMW seperti kesulitan dalam mendapatkan informasi tentang PKM dan PMW, pengumuman program yang mendadak, kesulitan dalam mendapatkan ide dan menulis, kesulitan dalam mendapatkan dosen pembimbing, dan kesulitan untuk menemukan tim.
\end{abstract}

Kata-kata kunci: Program Kreativitas Mahasiswa (PKM), Program Mahasiswa Wirausaha (PMW), soft skill.

\section{ABSTRACT}

Program Kreativitas Mahasiswa (PKM) and Program Mahasiswa Wirausaha (PMW), or student creativity program and student entrepreneurship program are to develop soft skills and student aspects such as affective, cognitive, and psychomotor. The program provides benefits for both students and institutions. A lot of efforts have been conducted by Fakultas Bahasa dan Seni (FBS) Universitas Pendidikan Ganesha (Undiksha) in increasing the quantity and quality of PKM and $P M W$. However, the quantity and quality are still a deficiency. In this study, the deficiency causes of the PKM and PMW in FBS Undiksha was investigated. The ADDIE (Analysis, Design, Development or Production, Implementation or Delivery, and Evaluations) was applied from the obtained data through the interview method from 91 students of FBS Undiksha. The results showed that the primary cause of deficiency was experienced by the students when joining the 
PKM and PMW. There were several obstacles encountered by students, such as the difficulty in getting information about PKM and PMW, the sudden announcement of the program, the stress in getting ideas and writing, the stress in getting the supervisors, and the difficulty to find the teams.

Keywords: student creativity program, student entrepreneurship program, soft skills

\section{PENDAHULUAN}

Revolusi 4.0 merupakan tantangan hebat dalam kehidupan saat ini karena hal ini berimplikasi dan menimbulkan perubahan dalam berbagai sisi kehidupan. Dengan berbagai perkembangan tersebut, persaingan pun akan semakin ketat dan terbuka. Kemampuan yang dibutuhkan untuk menghadapi persaingan masa kini juga menjadi semakin tinggi dan kompleks, meliputi pengetahuan akademik, keterampilan berpikir, keterampilan dalam manajemen, dan keterampilan komunikasi. Pendidikan tinggi memiliki peran yang sangat penting untuk menyiapkan generasi yang memiliki berbagai keterampilan tersebut secara komprehensif. Berbagai program pun dibuat untuk menjadi wadah bagi mahasiswa dalam mengembangkan kemampuannya. Salah satu program yang dapat diikuti oleh mahasiswa adalah Program Kreativitas Mahasiswa (PKM) dan Program Mahasiswa Wirausaha (PMW), yang belakangan ini selalu dikompetitipkan oleh Kemenristek yang dapat menunjukkan keunggulan sebuah perguruan tinggi.

Di Undiksha, PKM telah dilaksanakan sejak tahun 2001. Sementara, PMW mulai dilaksanakan sejak tahun 2009. Kedua program tersebut bertujuan untuk meningkatkan kreativitas mahasiswa dan pengalaman serta jiwa kewirausahaan mahasiswa. Dikti (2018). disebutkan, PKM terdiri atas beberapa skema, yang meliputi PKM Penelitian (PKM-P), PKM-Kewirausahaan (PKM-K), PKM-Pengabdian kepada Masyarakat (PKMM), PKM-Penerapan Teknologi (PKM-T), PKM Karsa Cipta (PKM-KC), PKM-Artikel Ilmiah), PKM Gagasan Tertulis (PKM-GT), PKM Gagasan Futuristik Konstruktif (PKMGFK). Seluruh skema PKM tersebut dimaksudkan untuk menumbuhkembangkan HOTS (Higher Order Thinking Skills), creative thingking, dan critical thinking mahasiswa. Hal ini sejalan juga dengan pembelajaran berbasis HOTS sebagaimana yang diungkapkan oleh Apandi (2018) untuk menyongsong kecakapan abad 21 atau 4C yang meliputi (1) Communication (komunikasi), (2) Collaboration (kolaborasi), (3) Critical thinking and problem solving (berpikir kritis dan menyelesaikan masalah), (4) Creative and innovative (kreatif dan inovatif).

Terdapat berbagai jenis PKM di sebuah perguruan tinggi. Tahapan pelaksanaan PKM akan berbeda-beda sesuai dengan jenis PKM. Secara umum, setelah pengajuan PKM dibuka, mahasiswa diwajibkan untuk mengajukan proposal PKM, kemudian dilakukan seleksi, pengumuman PKM yang didanai, dan pelaksanaan PKM. Selain menjadi peluang untuk meningkatkan kreativitas dan kemampuan mahasiswa, program ini juga memberikan keuntungan langsung bagi mahasiswa berupa bantuan dana untuk mewujudkan gagasan kreatif mahasiswa (Putra, dkk., 2018). Bagi perguruan tinggi, capaian mahasiswa dalam bidang PKM maupun PMW berkontribusi pada capaian akreditasi lembaga baik pada tingkat program studi maupun universitas. Mengingat manfaat dan pentingnya program ini, PKM perlu dikelola dengan sungguh-sungguh.

Dalam meningkatkan kinerja serta unjuk kerja antarperguruan tinggi, Universitas Pendidikan Ganesha telah mengelola program ini dengan serius. Beberapa kegiatan yang 
dilakukan secara rutin oleh universitas adalah memberikan pelatihan PKM dan PMW kepada mahasiswa. Pelatihan ini dilaksanakan pada tingkat lembaga dan diikuti oleh perwakilan mahasiswa. Universitas juga membentuk kelompok kerja (pokja) mahasiswa yang menangani bidang PKM dan PMW. Bahkan beberapa tahun terakhir telah dibentuk unit kegiatan mahasiswa dalam bidang penulisan karya ilmiah.

Pada tingkat fakultas juga dilakukan kegiatan sejenis untuk meningkatkan kualitas dan kuantitas PKM dan PMW mahasiswa. Fakultas Bahasa dan Seni memiliki kelompok kerja (pokja mahasiswa) yang khusus bertugas menangani urusan PKM dan PMW mahasiswa. Pokja tersebut berada di bawah koordinasi Badan Eksekutif Mahasiswa Fakultas Bahasa dan Seni. Kegiatan yang secara rutin diselenggarakan oleh pokja meliputi pelatihan penulisan proposal PKM, pendampingan penulisan proposal PKM, serta menyosialisasikan program PKM kepada mahasiswa di lingkungan FBS.

Selain upaya-upaya tersebut, lembaga juga mendorong peningkatan kuantitas dan kualitas PKM dan PMW dengan cara mewajibkan pelamar beasiswa untuk menyertakan rancangan proposal PKM dan PMW sebagai salah satu syarat dalam pengajuan beasiswa. Namun, berbagai upaya tersebut tampaknya belum cukup untuk meningkatkan kualitas dan kuantitas PKM dan PMW khususnya di Fakultas Bahasa dan Seni. Pada tahuan 2016 hingga 2018, tidak ada mahasiswa FBS yang lolos pada program PKM. Pada tahun 2015, terdapat 10 judul PKM yang didanai. Pada tahun sebelumnya, tahun 2014, terdapat 8 PKM yang didanai, dan pada tahun 2013 terdapat 22 judul PKM yang didanai. Berdasarkan data tersebut, kuantitas PKM di lingkungan FBS cenderung mengalami fluktuasi. Jika dibandingkan dengan jumlah mahasiswa Fakultas Bahasa dan Seni, jumlah PKM tersebut masih tergolong rendah. Padahal, menurut Widjajanti (2011), pengalaman, keterampilan, dan keberhasilan mahasiswa dalam menggeluti suatu entrepreneur akan memberi bekal dalam kehidupan sosialnya kelak.

Berdasarkan rasional pemikiran di atas dapat diidentifikasi beberapa hal (1) terdapat permasalahan dalam pengajuan PKM dan PMW dan (2) model peningkatan peningkatan kualitas dan kuantitas PKM dan PMW mahasiswa FBS Undiksha perlu dikaji secara mendalam. Sejalan dengan permasalahan tersebut tujuan penelitian ini untuk (1) mendeskripsikan permasalahan dalam pengajuan PKM dan PMW oleh mahasiswa Fakultas Bahasa dan Seni Undiksha dan (2) mendesain model peningkatan kualitas dan kuantitas PKM dan PMW mahasiswa Fakultas Bahasa dan Seni.

\section{METODE}

Penelitian ini menggunakan rancangan model pengembangan ADDIE (Research and Development). ADDIE merupakan singkatan dari Analysis, Design, Development or Production, Implementation or Delivery and Evaluations (Branch, 2009). Dalam model ini ada lima tahapan penting yang harus diperhatikan. Kelima tahapan tersebut secara rinci dapat disampaikan sebagai berikut. Tahap I. Analisa (Analyze), pada tahapan ini ada beberapa kegiatan yang akan dilakukan yaitu, analisis terhadap kualitas PKM dan PMW mahasiswa Fakultas Bahasa dan Seni, analisis proses pengajuan PKM dan PMW.

Tahap II. Perancangan (Design), pada tahap perancangan (design) dilakukan beberapa kegiatan: perancangan jenis-jenis PKM dan PMW yang potensial untuk diikuti oleh mahasiswa Fakultas Bahasa dan Seni dan merancang pola pengajuan PKM dan PMW di Fakultas Bahasa dan Seni mulai dari proses persiapan hingga pelaporan dan evaluasi program. Tahap III. Pengembangan (Develop), tahap develop adalah produksi 
dan pascaproduksi. Tahapan produksi merupakan tahapan pengembangan rancangan proses pelaksanaan PKM dan PMW di lingkungan Fakultas Bahasa dan Seni Undiksha serta pengembangan booklet Model.

Tahap IV. Implementasi (Implementation), pada tahap ini, dilakukan implementasi model pelaksanaan PKM dan PMW yang telah dirancang. Sebelum implemetasi, booklet yang merupakan hasil dari langkah-langkah sebelumnya akan dicetak dan disosialisasikan kepada mahasiswa. Tahap V. Evaluasi (Evaluation), evaluasi dapat didefinisikan sebagai sebuah proses yang dilakukan untuk memberikan penilaian terhadap model pelaksanaan PKM dan PMW di lingkungan Fakultas Bahasa dan Seni. Dalam implementasinya tahapan-tahapan itu diikuti secara saksama sehingga diperoleh data sesuai harapan yang dapat meningkatkan kuantitas dan kualitas penyusunan PKM dan PMW di Fakultas bahasa dan Seni. Kajian ini berada pada tahap awal yakni analisis problematika yang dihadapi oleh mahasiswa dalam penyusunan PKM dan PMW.

\section{HASIL DAN PEMBAHASAN}

Hasil dan pembahasan penelitian pada penelitian ini dibagi menjadi dua subbab yang menguraikan masing-masing rumusan permasalahan penelitian. Yakni permasalahan dalam pengajuan PKM dan PMW mahasiswa Fakultas Bahasa dan Seni serta model peningkatan kualitas dan kuantitas PKM dan PMW Fakultas Bahasa dan Seni Undiksha.

\section{Permasalahan Pengajuan PKM dan PMW Mahasiswa Fakultas Bahasa dan Seni}

Pelaksanaan PKM direncanakan dan dilaksanakan dengan tahapan yang jelas dan sistematis. Mulai dari pengusulan dan seleksi pada tingkat perguruan tinggi hingga kegiatan di tingkat nasional berupa pelaksanaan Pekan Ilmiah Nasional (Pimnas). Berikut ini adalah tahapan pelaksanaan PKM untuk menjadi dasar dalam mengidentifikasi permasalahan mahasiswa dalam mengajukan dan melaksanakan PKM. Yang pertama adalah penyusunan proposal. Kegiatan ini dilaksanakan pada tingkat unversitas. Yang kedua adalah evaluasi internal, unggahan berita acara evaluasi, mendaftarkan judul dan ketua tim pengusul dan membuat akun ketua dan tim pengusul. Kegiatan tahap dua ini juga dilakukan di tingkat perguruan tinggi. Tahap ketiga adalah pengunggahan propsal PKM 5 bidang. Yang keempat, evaluasi daring tahap 1 dan evaluasi daring tahap 2 PKM 5 Bidang. Yang kelima, keputusan pendanaan PKM 5 bidang. Kemudian, penugasan dan kontrak PKM 5 bidang. Yang ketujuh, pelaksanaan PKM 5 bidang dengan mengerjakan logbook dan laporan kemajuan, serta unggahan laporan kemajuan. Tahap selanjutnya adalah monitoring dan evaluasi eksternal pelaksanaan PKM 5 bidang. Kesembilan adalah analisis hasil monev PKM 5 bidang dan penetapan judul PKM 5 bidang, PKM GT dan PKM GFK peserta pimnas. Yang terakhir adalah tahapan pelaksanaan Pimnas.

Di Undiksha, kegiatan penyusunan proposal dilakukan dan dikoordinasikan pada tingkan fakultas. Setiap fakultas, termasuk Fakultas Bahasa dan Senin (FBS) memiliki program dalam rangka memfasiltasi dan membatu mahasiswa dalam menyusun proposal PKM. FBS secara berkelanjutnan memprogramkan pelatihan penyusunan PKM. Kegiatan ini menjadi program tahunan Badan Eksekutif Mahasiswa FBS. Setelah pelatihan, pimpinan bidang kemahasiswaan FBS juga mewajibkan mahasiswa penerima besiswa untuk menyetorkan draf proposal PKM sebagai salah satu syarat dalam pengajuan beasiswa. Hal lain, mahasiswa baru juga telah diperkenalkan dan diarahkan untuk menulis 
proposal sejak masa orientasi kehidupan kampus dalam bentuk tugas pembuatan draf proposal. Kegiatan ini mengacu dan beradaptasi pada Renstra Undiksha (2015).

Meskipun upaya itu telah dilaksanakan, kualitas dan kuantitas PKM di FBS tampak masih belum memuaskan. Data dua tahun terakhir menunjukkan bahwa pada tahun 2018, hanya terdapat satu judul PKM yang didanai. Pada tahuan 2019, tidak terdapat satu pun PKM mahasiswa FBS yang lolos dan didanai. Hal ini menunjukkan bahwa masih perlu upaya untuk meningkatkan kualitas dan akhirnya kuantitas PKM di FBS. Berdasarkan kajian yang telah dilakukan, terdapat beberapa hambatan dan permasalahan yang terutama dialami oleh mahasiswa dalam pembuatan PKM.

Permasalahan pertama yang dapat diidentifikasi adalah mahasiswa tidak memiliki cukup informasi tentang kegiatan PKM. Kegiatan pengenalan PKM yang dilakukan dalam kegaitan orientasi mahasiswa baru hanya dilakukan secara sepintas yakni dengan meminta mahasiswa baru membuat draf proposal PKM. Mahasiswa baru tidak diberikan tentang wawasan PKM dan pelatihan penulisan PKM. Meskipun setiap mahasiswa telah membuat draf tersebut sebagai tugas, namun tidak ada tanggapan atau komentar atas isi. Selain itu, keberlanjutan atas pengenalan PKM itu setelah mahasiswa baru aktif sebagai mahasiswa juga tidak ada. Pada kegiatan OKK, informasi rinci tentang jenis-jenis PKM, kalender pelaksanaan, dan strategi lebih rinci juga tidak disampaikan.

Selain mahasiswa baru, mahasiswa yang telah kuliah pada tahun kedua, ketiga, dan yang lebih senior juga tidak banyak yang mengetahui informasi tentang PKM. Informasi PKM yang dimaksud meliputi, jenis-jenis PKM, kalender pelaksanaan PKM, tahapan pelaksanaan program PKM, pendanaan, struktur penulisan, dan termasuk strategi penulisan PKM.

Hasil wawancara dengan mahasiswa menunjukkan bahwa mahasiswa tidak mencari atau mendapatkan informasi yang memadai. Mahasiswa mengetahui istilah PKM hanya secara umum, tapi tidak mengetahui jenis-jenis dan mekanisme yang lebih teknis. Informasi tentang PKM yang mahasiswa peroleh hanya dari kegiatan OKK dan sekilas dalam obrolan sehari-hari oleh beberapa mahasiswa. Pimpinan program studi, jurusan, fakultas, dan dosen kurang menyampaikan informasi tentang PKM dan memberikan motivasi bagi mahasiswa untuk menulis PKM.

Dengan kecanggihan teknologi, informasi tentang PKM bisa didapatkan dengan mudah melalui internet. Namun, belum terbentuknya budaya menulis, meneliti dan berkompetisi dalam PKM membuat mahasiswa membutuhkan motivasi eksternal dan langkah-langkah yang lebih sistematis dan terbimbing dalam menulis dan mengikuti seleksi PKM.

Permasalahan kedua adalah meskipun menjadi syarat untuk melamar beasiswa, PKM tidak menjadi perhatian serius dalam penentuan penerima beasiswa maupun evaluasi terhadap penerima beasiwa. Draf proposal yang dibuat untuk seleksi beasiswa tidak ditindaklanjuti dengan proses yang lebih serius untuk mengirim proposal ke seleksi PKM. Untuk kepentingan seleksi beasiswa, proposal PKM juga tidak melalui proses pembimbingan dengan dosen pembimbing KKN layaknya proposal PKM yang akan disertakan dalam seleksi. Saat seleksi beasiswa, juga tidak terdapat pengecekan kualitas proposal yang dilampirkan oleh mahasiswa. Setelah seleksi beasiswa, keberlanjutan proposal juga tidak dicek dan dilakukan pembinaan untuk mengikutsertakan proposal tersebut dalam seleksi PKM. 
Yang ketiga, pelatihan PKM yang dilakukan belum berkontribusi optimal dalam meningkatkan kualitas dan kuantitas PKM mahasiswa Fakultas Bahasa dan Seni Undiksha. Pelatihan PKM merupakan program kerja rutin Badan Eksekutif Mahasiswa FBS. Meskipun telah dilakukan secara berkala dan dengan dana yang relatif memadai, hal ini belum mampu meningkatkan jumlah mahasiswa yang lolos dalam seleksi PKM. Bahkan, kegiatan tersebut belum mampu meningkatkan jumlah mahasiswa yang mengajukan proposal PKM.

Pelatihan PKM selama ini dilakukan dengan menghadirkan narasumber yang merupakan pakar atau reviewer PKM nasional dengan harapan mampu memberikan gambaran dan bimbingan kepada mahasiswa dalam menulis dan akhirnya lolos dalam seleksi PKM. Kegiatan tersebut dilakukan selama satu hari. Namun, yang selama ini terjadi adalah mahasiswa tidak melanjutkan hal yang dilatihkan dalam pelatihan tersebut sehingga menjadi proposal yang berkualitas untuk diikutkan seleksi PKM. Hal yang perlu dipertimbangkan selanjutnya adalah menegaskan komitimen peserta pelatihan untuk merancang PKM untuk diajukan dalam seleksi, mendesain pendampingan penulisan, dan membantu pendanaan dalam proses pengadaan proposal PKM.

Permasalahan keempat adalah peran kelompok kerja Karya Ilmiah Mahasiwa (Pokja KIM yang masih perlu dioptimalkan. Pokja merupakan bidang yang dibentuk secara khusus untuk membidangan PKM dan PMW. Namun, selama ini, pokja tidak mendapatkan anggaran dana yang memadai dan belum memiliki program kerja yang rinci dan secara baik disosialisasi. Pokja selama ini berkegiatan hanya pada saat pelaksanaan pelatihan. Fungsi pendampingan penyusunan proposal maupun sosialisasi tentang program PKM belum secara optimal dilaksanakan.

Permasalahan kelima, keterlibatan dosen, pimpinan prodi, pimpinan jurusan, dan fakultas masih perlu dioptimalkan dalam mendorong mahasiswa menulis PKM. Berdasarkan hasil wawancara, dosen yang mendorong mahasiswa untuk menulis PKM dalam perkuliahan dan mengaitkan materi kuliah dengan program PKM masih sangat terbatas. Selama ini, mahasiswa menentukan pembimbing PKM sendiri tanpa berkoordinasi dengan pimpinan di tingkat prodi atau jurusan. Dengan kata lain, belum ada mekanisme yang sistematis untuk melibatkan dosen, pimpinan prodi, dan pimpinan jurusan dalam rangka mendorong peningkatan kualitas dan kuantitas mahasiswa yang mengikuti program PKM.

Berdasarkan angket yang telah direspons oleh 91 orang mahasiswa, diketahui beberapa informasi sebagai berikut. Informasi yang dikumpulkan melalui angket meliputi informasi tentang sumber informasi tentang PKM, apakah mahasiswa pernah membaca buku panduan PKM, apakah mahasiswa mengetahui jenis-jenis PKM, apakah mahasiswa pernah menulis PKM, apakah PKM yang ditulis pernah lolos dan didanai, apakah mahasiswa pernah mengikuti PIMNAS, apakah mahasiswa pernah mengikuti sosialisasi PKM, dimanakah mahasiswa mengkikuti sosialisasi PKM, Apakah pimpinan fakultas, jurusan dan prodi serta dosen pernah memberikan informasi dan motivasi untuk mengikuti PKM, apakah dosen pernah menghubungan mata kuliah yang diajarkan dengan PKM, apakah teman pernah memberikan motivasi untuk menulis PKM, apakah hambatan dalam menulis PKM, serta respons mahasiswa jika proposal PKM menjadi salah satu prasyarat pengajuan permohonan beasiswa.

Dari informasi pertama mengenai pengetahuan mahasiswa tentang PKM didapatkan bahwa 98,9\% mahasiswa mengetahui tentang adanya PKM dan hanya 
terdapat 1 mahasiswa $(1,1 \%)$ yang tidak mengetahui tentang program tersebut. Dari 98,9\% mahasiswa yang mengetahui tentang aktivitas PKM, beberapa sumber informasi yang mereka peroleh diperlihatkan pada gambar 1.
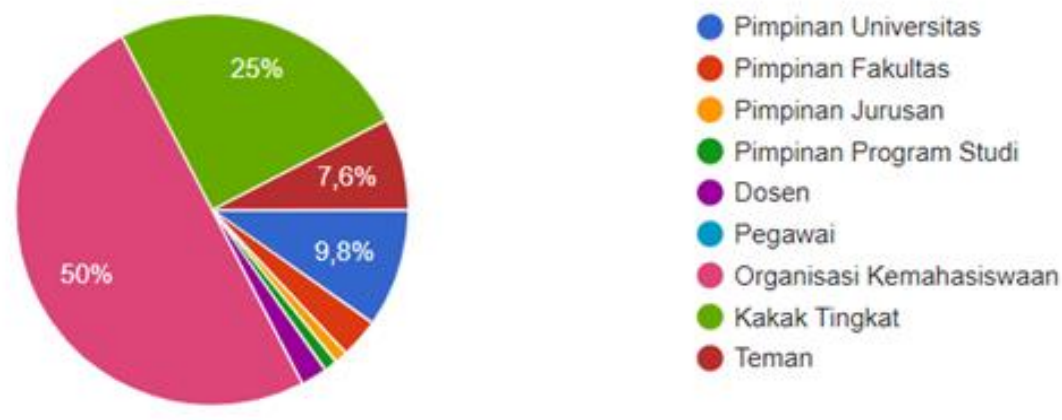

\section{Gambar 1. Sumber informasi mengenai PKM}

Seperti terlihat pada gambar 1, sebanyak 50,5\% mahasiswa memperoleh informasi dari organisasi kemahasiswaan, 24,2\% dari kakak tingkat, 9,9\% dari pimpinan universitas, $7,7 \%$ dari teman, 3,3\% dari pimpinan fakultas, $2,2 \%$ dari dosen, dan $1,1 \%$ dari pimpinan jurusan dan pimpinan program studi masing-masing. Selanjutnya, data menunjukkan bahwa 93,4\% mahasiswa penah membaca panduan PKM. Hanya 6,6\% mahasiswa yang tidak pernah membaca buku panduan PKM. Hal ini menunjukkan bahwa mahasiswa memiliki minat yang relatif tinggi untuk mengetahui program kreativitas mahasiswa. Seluruh mahasiswa (100\%) mengetahui jenis-jenis PKM yang dapat dipilih untuk diikuti.

Mahasiswa Fakultas Bahasa dan Seni yang pernah menulis PKM juga tinggi mencapai $97,8 \%$. Hanya 2,2\% mahasiswa yang belum pernah menulis PKM. Peran penulisan PKM tidak dibedakan baik sebagai ketua penulis maupun anggota. Meskipun jumlah mahasiswa yang pernah menulis proposal PKM sangat tinggi, ternyata jumlah proposal yang lolos dan didanai sangat kecil, yakni hanya 1 proposal $(1,1 \%)$ mahasiswa yang proposalnya pernah lolos dan didanai. Bahkan, tidak satu pun mahasiswa Fakultas Bahasa dan Seni yang pernah mengikuti Pekan Ilmiah Mahasiswa Nasional (PIMNAS) yang merupakan ajang puncak penyelenggaraan PKM dan PMW tingkat nasional.

Lembaga, baik pada tingkat universitas hingga program studi sudah melakukan berbagai upaya dalam meningkatkan kualitas dan kuantitas PKM mahasiswa. Upaya itu dilakukan dalam bentuk sosialisasi mengenai PKM, pelatihan, pembentukan kelompok kerja, hingga pendampingan. Hal tersebut dapat diketahui dari repons mahasiswa yang menyatakan bahwa $80,2 \%$ pernah mengikuti sosialisasi mengenai PKM. Dari keseluruhan mahasiswa yang pernah mengikuti sosialisasi PKM, 83,55 di antaranya mengikuti sosialisasi yang diselenggarakan oleh universitas, $11 \%$ mengikuti sosialisasi yang deselenggarakan oleh fakultas, $3 \%$ mengikuti yang diselenggarakan oleh jurusan, dan 2,2\% mengikuti sosialisasi yang diselenggarakan oleh program studi.

Respons mahasiswa melalui kuesioner juga menunjukkan bahwa pimpinan fakultas, jurusan, hingga program studi telah memberikan informasi dan motivasi terkait PKM. Sebagian besar mahasiswa, yakni $81,3 \%$ menyatakan bahwa pimpinan fakultas pernah memberikan informasi dan moivasi tentang penulisan PKM. Sejumlah $72,5 \%$ 
mahasiswa menyakan bahwa pimpinan jurusan pernah memberikan informasi dan motivasi tentang penulisan PK kepada mahasiswa. Sedikit lebih tinggi dari itu, 73,6\% mahasiswa menyatakan bahwa pimpinan program studi juga memberikan informasi dan motovasi kepada mahasiswa untuk menulis PKM. Hal ini menunjukkan bahwa, pimpinan fakultas, jurusan, dan program studi juga telah memberikan perhatian khusus kepada mahasiswa untuk terlibat dalam penulisan PKM.

Selanjutnya, pihak dosen juga memberikan informasi dan motivasi kepada mahasiswa terkait PKM. Sejumlah 70,3\% mahasiswa menyatakan bahwa dosen telah memberikan informasi dan motivasi kepada mahasiswa untuk mengikuti kegiatan PKM. Bahkan, 40,7\% mahasiswa menyatakan bahwa dosen telah menghubungan mata kuliah yang diajarkan dengan PKM. Dengan demikian, diharapkan mahasiswa memiliki gagasan yang lebih linier dengan bidang yang dipelajarinya. Mahasiswa juga diharapkan menjadi lebih mudah dalam menyusun proposal PKM karena sudah memiliki pengetahuan yang memadai tentang topik terkait yang diperolehnya melalui kegiatan pembelajaran di kelas.

Sebanyak $71,4 \%$ mahasiswa menyampaikan bahwa selain pimpinan perguruan tinggi, fakultas, jurusan, program studi, dan dosen, teman-teman sejawat juga sering memberikan motivasi dan informasi terkait PKM. Sejumlah 71,4\% mahasiswa menyampaikan bahwa teman sejawat mahasiswa juga memberikan informasi dan motivasi untuk mengikuti dan menulis proposal PKM.

Hambatan yang dialami mahasiswa dalam menyusun proposal PKM cukup beragam seperti yang terlihat pada gambar 2 .

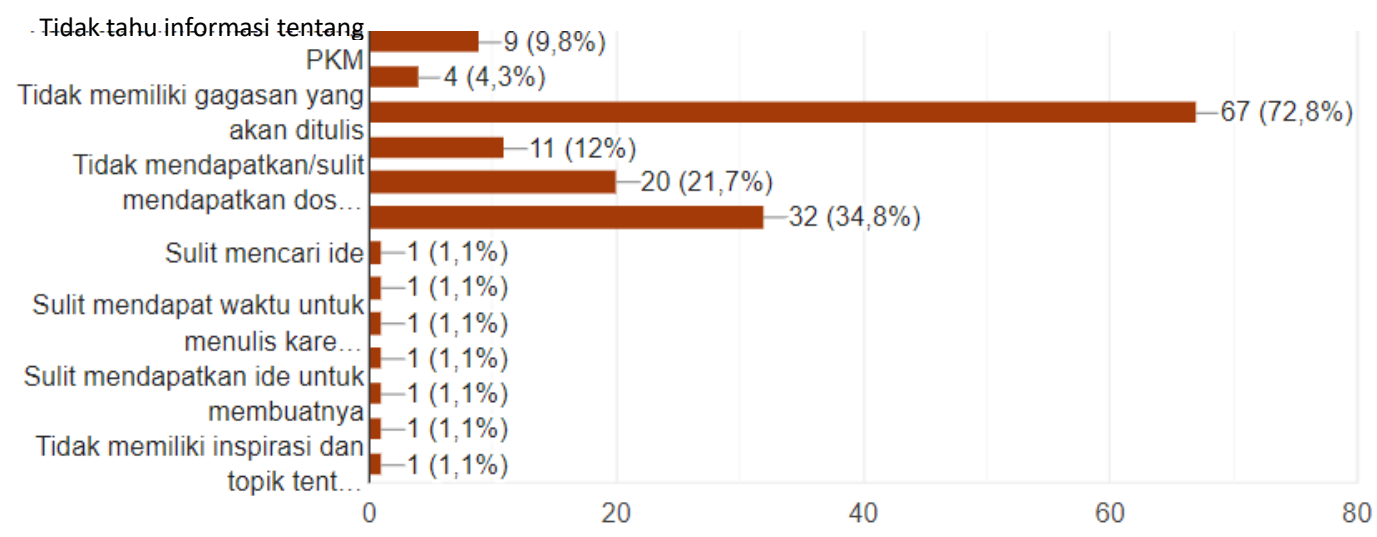

Gambar 2. Hambatan mahasiswa dalam menyususn proposal PKM

Sejumlah 66 mahasiswa $(72,5 \%)$ menyampaikan bahwa hambatan mahasiswa adalah tidak memiliki gagasan untuk ditulis. Hambatan ini menjadi hambatan yang paling tinggi dialami oleh mahasiswa. Hambatan tertinggi kedua adalah sulit mendapatkan tim dalam menyusun proposal. Sejumlah 32 mahasiswa atau 35,2\% mahasiswa menyatakan bahwa mahasiswa sulit mendapatkan tim menyususn proposal. Tim dalam penyususnan proposal harus memenuhi ketentuan batas semester dan sebaiknya memperhatikan dengan ketentuan program studi. Mahasiswa dimungkinkan untuk bertim dengan mahasiswa yang berbeda program studi dan lintas semester.

Hambatan yang ketiga adalah tidak mendapatkan atau sulit mendapatkan dosen pembimbing dalam menyusun proposal PKM. Sejumlah 20 mahasiswa atau $22 \%$ 
mahasiswa menyatakan tidak mendapatkan atau sulit mendapatkan dosen pembimbing dalam proses penyusunan hingga pengajuan proposal PKM.

Hambatan keempat mahasiswa dalam menulis proposal PKM adalah tidak mengetahui cara penulisan. Sebanyak 11 orang mahasiswa atau 12,1\% mahasiswa menyatakan tidak mengetahui cara penulisan PKM. Yang dimaksud dengan cara penulisan meliputi sistematika, isi masing-masing komponen, dan strategi penulisan. Hambatan kelima mahasiswa adalah tidak mengetahui informasi tentang PKM. Terdapat 9 orang mahasiswa atau $9,9 \%$ mahasiswa yang menyatakan tidak mengetahui informasi tentang PKM. Informasi yang dimaksud khususnya adalah tentang jadwal dan sistematika pelaksanaan PKM. Hambatan keenam mahasiswa adalah tidak mengetahui syarat penulisan. Sebanyak 4 orang mahasiswa menyampaikan tidak mengetahui syarat-syarat penulisan proposal PKM. Hambatan-hambatan lain yang juga dialami oleh mahasiswa yang dengan persentase yang sangat kecil antara lain takut salah dan takut mencoba, tidak memiliki waktu untuk menulis PKM.

Pimpinan Fakultas Bahasa dan Seni, khususnya bidang kemahasiswaan telah mensyaratkan proposal PKM saat mahasiswa mengajukan permohonan beasiswa. Hal tersebut ditanggapi positif oleh mahasiswa. Sebanyak 94,5\% mahasiswa menyatakan membuat proposal dengan sungguh-sungguh dalam menulis proposal. Selain untuk memenuhi syarat pengajuan PKM, mahasiswa juga akan mengajukan proposal tersebut dalam seleksi PKM. Hanya terdapat 4,4\% mahasiswa yang menyatakan tidak akan membuat proposal dengan sungguh-sungguh karena proposal tersebut hanya untuk memenuhi syarat pengajuan permohonan beasiswa.

\section{Model Peningkatan Kualitas PKM dan PMW Mahasiswa Fakultas Bahasa dan Seni}

Upaya peningkatan kualitas dan kuantitas PKM di Fakultas Bahasa dan Seni melibatkan banyak aspek di antaranya sistem pelatihan dan seleksi, kebijakan pimpinan universitas hingga tingkat program studi, sistem pelatihan dan pendampingan penulisan proposal PKM, budaya menulis dan berpikir kritis mahasiswa, kreativitas mahasiswa, dan motivasi. Upaya yang dilakukan pemimpinan fakultas selama ini yakni dengan mensyaratkan dilampirkannya proposal PKM belum efektif untuk meningkatkan kalitas PKM. Hal tersebut baru hanya dapat meningkatkan kuantitas PKM yang pernah dibuat oleh mahasiswa. Meskipun mahasiswa telah membuat proposal PKM, proposal PKM yang didanai cenderung masih sangat kecil bahkan tidak ada. Hal ini ditunjukkan juga oleh hasil angket yang menyatakan bahwa 97,8\% mahasiswa Fakultas Bahasa dan Seni pernah menulis PKM. Tingginya jumlah mahasiswa yang pernah menulis PKM terkait dengan dijadikannya proposal sebagai prasysrat pengajuan permohonan beasiswa dan PKM juga dijadikan salah satu materi sosiallisasi saat orientasi kehidupan kampus.

Upaya yang dilakukan oleh pimpinan dalam rangka meningkatkan kualitas dan kuantitas PKM mahasiswa selama ini antara lain, pertama, melakukan pelatihan PKM yang dilaksanakan setiap tahun oleh Badan Eksekutif Mahasiswa Fakultas Bahasa dan Seni. Pelatihan PKM tersebut diselenggarakan dengan mengundang narasumber atau pelatih luar yang memiliki peran sebagai reviewer PKM di tingkat pusat. Dengan demikian, mahasiswa diharapkan lebih memahami proses penulisan PKM termasuk mengidentifikasi masalah dan topik menarik untuk PKM. Kedua, pimpinan fakultas khususnya bidang kemasiswaa, mewajibkan mahasiswa yang memperoleh beasiswa untuk menulis proposal PKM. Hal ini dilakukan untuk mendorong mahasiswa menulis. 
Ketiga, proposal PKM menjadi syarat dalam pengajuan beasiswa. Setiap pengajuan beasiswa, mahasiswa akan menyampaikan berkas seleksi. Salah satu komponan yang wajib ada pada berkas tersebut adalah proposal PKM. Upaya mewajibkan penerima beasiswa dan peserta seleksi beasiswa untuk menulis proposal PKM baru hanya dapat meningkatkan kuantitas proposal PKM. Sementara kualitas PKM yang dapat diketahui dengan lolos tidaknya PKM tersebut masih sangat rendah. Meskipun jumlah mahasiswa yang pernah menulis PKM sangat tinggi, yakni mencapai 97,8\%, jumlah mahasiswa yang proposalnya pernah lolos dan didanai hanya 1,1\%. Dari keseluruhan mahasiswa Fakultas Bahasa dan Seni, tidak seorang pun pernah mengikuti kegiatan Pekan Ilmiah Mahasiswa Nasional yang merupakan ajak puncak serangkaian kegiatan PKM. Keempat, kelompok kerja (pokja) yang dibentuk pada tingkat fakultas belum optimal dalam menjalankan fungsinya dalam mengorganisasi kegiatan akademik termasuk PKM.

Berdasarkan angket yang diisi oleh mahasiswa diketahui bahwa mahasiswa mengharapkan beberapa hal dalam rangka meningkatkan kualitas dan kuantitas PKM dan PMW di Fakultas Bahasa dan Seni. Yang pertama adalah sosialialisasi yang lebih intensif dan berulang. Kedua, pelatihan yang lebih intensif. Ketiga, motivasi dosen pembimbing. Keempat, dosen pembimbing PKM lebih intensif membimbing mulai dari menemukan ide sampai proses penulisan. Kelima, bukan penerima bidikmisi saja yang difokuskan untuk menulis PKM melainkan seluruh mahasiswa diarahkan untuk berpartisipasi dalam PKM. Keenam, terdapat forum diskusi PKM pada tingkat fakultas untuk membahas tentang gagasan PKM dan aspek-aspek lain PKM. Kedelapan, adakan lomba penulisan PKM untuk intern fakultas. Kesembilan, hindari penyebaran informasi tentang tenggat pengumpulan PKM yang mendadak.

Berdasarkan kondisi yang dihadapi oleh mahasiswa, hambatan mahasiswa dalam menulis PKM, dan mengevaluasi kebijakan yang selama ini telah berlangsung, upaya peningkatan kualitas dan kuantitas PKM Fakultas Bahasa dan Seni dapat diupayakan beberapa hal. Pertama, membuat kalender kegiatan PKM yang telah disesuaikan dengan jadwal seleksi PKM. Kalender kegiatan PKM ini dimaksudkan untuk memberikan mahasiswa informasi tentang waktu pelaksanaan seleksi proposal PKM dan tahapantahapan kegiatan yang akan dilakukan untuk mempersiapkan proposal PKM yang diikutkan pada seleksi. Kedua, merancang sosialisasi yang lebih intesif dan berulang tentang PKM kepada seluruh mahasiswa. Sosialisasi ini dapat dilakukan oleh organisasi mahasiswa tingkat fakultas maupun tingkat jurusan. Sosialisasi juga dilakukan secara berulang agar menjangkau lebih banyak mahasiswa. Media sosialisasi dapat dilakukan melalui media sosial maupun media konvensional seperti pengumuman pada papan pengumuman di wilayah kampus. Keterlibatan pimpinan fakultas, jurusan, prodi, dan dosen juga sangat dibutuhkan. Mahasiswa sangat mengharapkan informasi dan bimbingan intensif dosen dalam proses persiapan hingga penulisan PKM. Ketiga, membuat pelatihan dan pendampingan penulisan proposal PKM. Meskipun pelatihan selama ini sudah dilakukan namun hal terebut masih belum optimal. Pelatihan tersebut belum ditindaklanjuti dengan pendampingan penulisan proposal. Dalam hal ini, dosen juga perlu diberikan sosialisasi pengenai program PKM dan lebih dilibatkan dalam pembimbingan dan pendampingan penulisan proposal PKM oleh mahasiswa.

Pelatihan PKM selama ini sudah mensyaratkan peserta untuk memiliki draf proposal terlebih dahulu. Namun, belum semua peserta memenuhi syarat tersebut sehingga kegiatan pelatihan belum bisa dilakukan secara sangat teknis untuk memperoleh 
masukan atas draf proposal yang dibuat. Dosen pembimbing juga tidak dilibatkan dalam sosialisasi dan pelatihan. Dosen pembimbing belum tentu memiliki informasi yang utuh tentang PKM dan belum tentu memiliki buku panduan PKM. Karena itu, pengomptimalan pelatihan PKM dapat dilakukan dengan mempersiapkan pelatihan lebih awal, termasuk proposal PKM yang akan disempurnakan melalui Pelatihan. Pelatihan tersebut juga sebaiknya melibatkan dosen pembimbing PKM.

Keempat, persyaratan PKM dalam pengajuan permohonan beasiswa masih perlu dipertahan dan dioptimalkan. Sejumlah 93,5\% mahassiwa menyatakan bahwa jika menjadi syarat permohonan beasiswa, mahasiwa akan membuat proposal PKM dengan sungguh-sungguh dan mengajukannya dalam seleksi PKM. Menyikapi hal ini, dibutuhkan perhatian yang lebih serius dan tindak lanjut atas kebijakan ini yakni dengan mensyaratkan PKM tersebut sudah melalui proses bimbingan dengan dosen pembimbing dan diketahui oleh ketua jurusan. Selama ini, proposal yang diajukan sebagai syarat permohonan beasiswa masih belum diwajibkan melalui proses bimbingan dan diketahui oleh pembimbing dan ketua jurusan. Dengan demikian, diharapkan mahasiswa lebih serius dalam menulis PKM, dosen lebih intensif dalam membimbing, dan pimpinan jurusan dapat memberikan pengarahan dan motivasi kepada mahasiswa.

Kelima, perlu diselenggarakan lomba penulisan PKM pada tingkat fakultas untuk membentuk iklim menulis karya ilmiah di kalangan mahasiswa. Hal ini sekaligus dapat menjadi ajang sosialisasi Program PKM. Peserta lomba dapat mengembangkan hasil karyanya seklaigus untuk diajukan pada seleksi PKM. Klasifikasi lomba dapat disesuaikan dengan jenis-jenis PKM yang sesuai dengan karakteristik Fakultas Bahasa dan Seni dan potensial untuk diikuti oleh mahasiswa.

Keenam, mengoptimalkan peran kelompok kerja yang telah dibentuk pada tingkat fakultas. Mahasiswa membutuhkan informasi dan pengalanan dari kakak tingkat tentang pengalaman ikut serta dalam seleksi PKM dan pengalanan dalam menulis PKM. Hal ini dapat menjadi salah satu program unggulan kelompok kerja PKM pada tingkat fakultas dengan memfasilitasi mahasiswa untuk mendapatkan informasi lengkap tentang PKM dan melakukan pendampingan dalam proses penulisan PKM. Untuk itu, pokja juga perlu memiliki dana untuk dikelola dalam melakukan berbagai kegiatan.

Ketujuh, pimpinan Fakultas Bahasa dan Seni pada saat ini sudah membentuk tim dosen pembina karya ilmiah mahasiswa yang terdiri atas tiga orang dari masing-masing jurusan. Tim telah dikukuhkan melalui SK Dekan Fakultas Bahasa dan Seni. Hal ini merupakan usaha dan upaya fakultas dalam meningkatkan kuantitas dan kualitas PKM dan PMW pada Fakultas Bahasa dan Seni.

\section{SIMPULAN}

Berdasarkan uraian pada hasil dan pembahasan dapat disimpulkan beberapa hal sesuai dengan rumusan masalah penelitian. Pertama, dalam pengikuti program PKM mahasiswa memiliki beberapa hambatan utama di antaranya, terbatasnya informasi tentang PKM, pengumuman seleksi PKM yang cenderung dianggap mendadak, mahasiswa sulit mendapatkan gagasan dalam menulis PKM, mahasiswa tidak mengetahui cara dan sistematika penulisan PKM, mahasiswa sulit mendapatkan dosen pembimbing, mahasiswa juga memiliki hambatan dalam menemukan tim yang akan diajak untuk menulis PKM. Yang kedua, peningkatan kualitas dan kuantitas PKM Fakultas Bahasa dan Seni dapat dilakukan dengan lebih mengoptimalkan upaya yang selama ini telah 
dilakukan dengan melakukan langkah-langkah kegitan sebagai berikut. Pertama, membuat kalender kegiatan PKM pada tingkat fakultas yang memuat informasi tentang jadwal proses persiapan, pelatihan, lomba, seleksi PKM, dan kegiatan lain terkait. Kedua, diadakan pelatihan dan pendampingan dengan terlebih dahulu menyiapkan proposal yang akan dibahas pada pelatihan tersebut. Persiapan pelatihan dan pelatihan juga harus melibatkan dosen pembimbing sehingga terjadi kesamaan persepsi tentang PKM. Ketiga, pimpinan fakultas, jurusan, dan program studi memberikan perhatian yang lebih intensif kepada mahasiswa untuk meningkatkan kualitas dan kuantitas PKM mahasiswa. Pimpinan tingkat jurusan dan program studi dapat mengarahkan mahasiswa untuk melakukan bimbingan dengan dosen-dosen tertentu yang ditugasi oleh pimpinan jurusan dan prodi. Keempat, memberikan perhatian yang lebih serius pada proposal PKM yang dikumpulkan oleh mahasiwa dalam rangka mengikuti seleksi beasiswa. PKM yang dikumpulkan dalam rangka mengikuti seleksi beasiswa diharapkan sudah melalui proses pembimbingan yang intensif dengan dosen pembimbing dan sudah diketahui oleh pimpinan tingkat jurusan atau program studi. Kelima, pembentukan tim dosen pembimbing PKM dan PMW yang benar-benar fokus membimbing mahasiswa dalam tataran penyusunan sampai penyelesaian laporan.

\section{DAFTAR PUSTAKA}

Apandi, Idris. 2018. Langkah Praktis Melakukan Penilaian Hots dalam Kompasiana. https://www.kompasiana.com/idrisapandi/5bedad11c112fe184b36be28/la. Diunduh 19 Mei 2020

Branch, Robert Maribe. 2009. Instructional Design: The ADDIE Approach. London: Springer.

Dikti. 2018. Pedoman Program Kreativitas Mahasiswa 2018. https://belmawa.ristekdikti.go.id/wp/Pedoman-PKM-2018.pdf. Diakses pada 10 Februari 2019.

Putra, Anggara Pramana, dkk. 2018. Program Kreativitas Mahasiswa dan Implikasinya dalam Upaya Sustainable Empowerment. Jurnal: Ranah Research. Vol.1. No.1:18.

Undiksha. 2015. Rancangan Strategis (Renstra). Singaraja: Undiksha Press.

Widjajanti, Kesi. 2011. Model Pemberdayaan Masyarakat. Jurnal Ekonomi Pembangunan, Volume 12, No.1, Juni 2011: hal. 15-27 